\title{
Cuarenta años de menendezpelayismo ${ }^{1}$
}

\author{
Marta M. Campomar Fornieles
}

Javier Tusell en el prólogo a la obra de Florentino Portero Franco Aislado, la Cuestión Española (1945-1950), opina respecto a la duración del régimen franquista: "la causa fundamental de que durara reside en que la herida de la guerra civil todavía estaba demasiado viva en los vencedores, como para que tuvieran otra cosa que miedo ante una posible reconciliación que para ellos pudo aparecer como la reversión de los resultados de la guerra civil»?

Guerra Civil, unión, reconciliación, vencedores y vencidos, alrededor de estos conceptos giran cuarenta años de menendezpelayismo que si bien se afianzó y desarrolló a raíz de la guerra civil, el fenómeno antecede a 1936. Tiene sus origenes en el siglo XIX, y en el "mito" de un personaje complejo y problemático de la Restauración, Don Marcelino Menéndez Pelayo.

Este análisis de cuarenta años de Menéndezpelayismo, forma parte de un capítulo de introducción a nuestra tesis doctoral sobre Menéndez Pelayo y las Polémicas Católicas de la Restauración (1875-1912), Universidad de Leeds, 1980. En esta sección se discute el uso o manipuleo del «mito" de Menéndez Pelayo por los criticos menéndezpelayistas, y por la política nacionalista católica desde 1912, hasta 1936. La perspectiva de este análisis, que mantenemos en nuestra ponencia, es la de un Menéndezpelayismo distorsionador de la persona de Menéndez Pelayo, que a su vez produce una falsificación de la historiografia del siglo XIX, de sus personalidades y de grupos que actuaron en la política religiosa de la Restauración. No es nuestra intención desarrollar el Menéndezpelayismo en toda su extensión ideológica, ni discutir la filiación política de sus protagonistas en el tiempo. Este enfoque merece otros estudios que esclarecerian la labor propagandistica de cuarenta años de Menéndezpelayismo dentro de una historia del Nacional Catolicismo de la era franquista. Lo nuestro es una mera aproximación al tema, demostrando cómo ciertos grupos del Nacional Catolicismo utilizaron a Don Marcelino para sus propios fines, o como argumento de apertura o cerrazón en la España de vencedores y vencidos en detrimento de un enfoque histórico adecuado. Intentamos resguardar la terminologia y el clima de retórica reiterativa, porque sólo asi se puede palpar la esencia del ideario menéndezpelayista y la insistencia de un mensaje o "lección" aprendida en el 36.

2 Florentino Portero. Franco Aislado. La Cuestión Española (1945-1950). Ed. Aguilar, Madrid, 1989. pág. 24. 
Efectivamente, no fueron causas externas ni la política internacional lo que permitió cuarenta años de Nacional Catolicismo Menendezpelayista. Fue más bien la memoria del drama interno, de una España durante dos siglos dividida, en dos, o más Españas, con guerras civiles y dinásticas, expulsión de catedráticos, exilio de intelectuales, levantamientos populares, golpes de estado militares, y un catolicismo nacionalista donde prevalecian una fuerte corriente de antiliberalismo integrista y tradicionalista. La continuidad no resuelta de estos y otros problemas, para el Menéndezpelayismo perpetuaron una "España con problemas", que unos consideran "superada" por los acontecimientos del 36, y otros como extendiéndose en la historia por falta de una reconciliación nacional auténtica, sin la cual no hay ni modernidad ni europeización.

El Menendezpelayismo a su modo, y con prudencia recicla este turbulento pasado, manipulando y tergiversando hechos históricos, personajes $y$ textos para reconstruir un ideario nacionalista que justificara el triunfo del 36 y proclamara una unión social falsa; porque la mitad de España, la llamada "roja", "heterodoxa" o "extranjerizante" quedara excluida de la nacionalidad o reducida al silencio. En el proceso sufre la integridad histórica de los textos que se citan, se confunden los "mitos" y las "glorias nacionales" con una apologética triunfalista, pero temerosa de perder terreno ganado en el 36 . Ante la inevitable modernización y secularización de la sociedad, y con los cambios que ya anticipaba el Concilio Vaticano II se nota el nerviosismo del Nacional Catolicismo que, por un lado lucha por mantenerse cerrado en sí mismo, y por el otro busca una «acción universal y europeísta". Oscilando entre una actitud de "revancha" o de "superación" de un pasado traumático, a toda costa se intenta resguardar la ortodoxia nacional reconquistada, esa "tradición interrumpida» de nación católica restaurada el 18 de julio y amenazada por el Comunismo y laicismo contemporáneo.

El Menendezpelayismo visto desde una perspectiva actual, nos resulta tan elemental, $\tan$ apologético y hasta ingenuamente antihistoricista, que sentimos la tentación de desecharlo como un trasto histórico sin trascendencia. Pero analizándolo cuidadosamente descubriremos que en medio de los argumentos que se repiten machaconamente, existe una complejidad ideológica de grupos de intelectuales que buscan acomodar sus inquietudes ideológicas a nuevas fórmulas de modernidad y apertura. Básicamente diremos que en el Menendezpelayismo existen tres grupos: el de los vencedores intolerantes, o integristas, cuya figura más representativa podría ser la de Jorge Vigón de Falange Española; la de los «desarrollistas» de la revista Arbor del Opus Dei, integristas pero con optimismo de futuro; y los llamados "liberaloides" o heterodoxos de "h" minúscula, 
representados por Pedro Laín Entralgo y Antonio Tovar. Dentro de estos tres grupos, el gran Menendezpelayismo (véase la extensa bibliografía de Simón Díaz para comprobar su proliferación) expresará sus propios matices ideológicos, que si no se destacan por su originalidad contienen bastante astucia para disfrazar lo que no se puede decir abiertamente, o para ocultar la crisis personal de ciertos menéndezpelayistas en evolución hacia un encuentro con la democracia. Todos ellos tienen algo en común que les une: el reciclaje del mito de Menéndez Pelayo para expresar más adecuada y solapadamente su propia postura ante el régimen franquista. Las "actualizaciones" y "vindicaciones" de la figura de Menéndez Pelayo, con distintas variantes y matices ideológicos responden a esta realidad.

Nacional Catolicismo y Menendezpelayismo fueron durante cuarenta años un mismo proyecto. Inicialmente entre 1938-1940 fue una empresa de recuperación nacional que barría por completo a la segunda España (la heterodoxa, antiespañola y antitradicionalista). Con un decreto del $19 \mathrm{de}$ mayo de 1938 (fecha en que murió Don Marcelino) el Instituto de España publica un decreto titulado Menéndez Pelayo y la Educación Nacional ${ }^{3}$ que pone en marcha un nuevo proyecto cultural. Las nuevas generaciones de institucionistas lo describen como «un delicioso compendio de tipo de Menendezpelayismo" ${ }^{4}$, pero Don Pedro Sáinz Rodríguez lo recuerda como un intento del gobierno de Franco por "elevar a la categoría de evangelio docente para la educación de nuestro pueblo» a las obras completas de Menéndez Pelayo. En 1975 Sáinz Rodríguez confiesa que este proyecto perjudicó la imagen de Don Marcelino, pero no niega la realidad histórica de que en los años de la postguerra se vivió como una empresa de recuperación de "la conciencia nacional colectiva" al servicio del interés nacional ${ }^{5}$. Florentino Pérez Embid en su artículo "Ante la Actualidad del Problema de España" es claro en este propósito: "vemos en las ideas de Don Marcelino el auténtico camino para la superación de

\footnotetext{
Menéndez Pelayo y la Educación Nacional, Instituto de España, Madrid, 1938. En este documento se citan todos los textos en que Menéndez Pelayo se enfrenta con los krausistas y con los defensores de la educación laica. Se citan los temas básicos de la cultura y pensamiento nacional en el "espiritu» de Menéndez Pelayo. Se aclara que no es un problema ni administrativo, ni político determinado, más bien un ideario para la educación nacional .

Véase En el Centenario de la Institución Libre de Enseñanza. Francisco Laporta y Virgilio Zapatero, "¿Por qué los jóvenes de hoy sin institución?". Ed. Tecnos, Madrid, 1977. pág. 224. En este mismo libro el articulo de Elías Díaz «La Institución Libre de Enseñanza en la España del Nacional Catolicismo", donde se incluye al autor de los Heterodoxos en la campaña de destrucción de la razón y de los intelectuales de la postguerra. pp. 147-174.

5 Pedro Sáinz Rodríguez, Menéndez Pelayo, Desconocido. Fundación Universitaria Española, Madrid, 1975.
} 
la trágica antinomia que desde hace siglo y medio ha conducido inexorablemente a los españoles a una guerra civil cada cuarto de siglo. Por eso Arbor ha proclamado este mismo año (1949) su fundamental fidelidad a la concepción española de Menéndez Pelayo" 6 .

La guerra civil era una realidad palpable que nadie se atrevia a negar. Seguía latente en el Menendezpelayismo y se interponía a cualquier proyecto de unidad nacional. Don Miguel Artigas en 1939 cambia el contenido culturalmente más objetivo del Menendezpelayismo del Boletín de la Biblioteca de Menéndez Pelayo Santander, hacia un nuevo rumbo militante y apologético que prevalecerá en la crítica de las obras de Menéndez Pelayo en general. En su biografía La Vida y obra de Menéndez Pelayo, anuncia que "una tragedia espantosa se ha desencadenado en España" ${ }^{7}$, que no es sólo la guerra civil, sino la desnacionalización y descristianización del pensamiento español, bajo color de progreso y europeización. En esta tragedia, opina Artigas, los hombres honrados buscan una fuente pura de verdadera vida espiritual que los españoles nunca debian haber perdido. La fuente será Menéndez Pelayo, pero no el de las Estéticas o los Orígenes de la Novela del Boletín de $1919^{8}$, sino el de La Polémica de la Ciencia Española y la Historia de los Heterodoxos, obras favoritas del Menendezpelayismo y del catolicismo nacionalista desde 1912 año en que falleció Don Marcelino y se puso en marcha el mito militante ${ }^{9}$.

La guerra civil era recordada por los Menendezpelayistas como un acontecimiento traumático para varias generaciones. Laín Entralgo, citado por Arbor, dice: "la mía es una generación sangrienta y espiritualmente astillada" (Arbor pág. 155), experiencia personal que remonta a la generación del 98 y hasta la del 68 de la Restauración. Le responde Rafael Calvo Serer en Arbor, que la solución no es revolver en el destino nacional

6 En la Revista Arbor del año 1949 - Vol. 14. № 5 se publican los artículos de Pérez Embid y Calvo Serer. El de Pérez Embid "Ante la Actualidad del Problema de España». pp. 149-160; pág. 153 . 1939.

Miguel Artigas, La Vida y Obra de Menéndez Pelayo. Ed. Heraldo de Aragón, Zaragoza,

8 En 1919 Artigas funda el Boletin como una obra "nacida del anhelo de cultivar la semilla que el inolvidable autor de "Los origenes de la novela", arrojó a manos llenas en los diversos campos de la erudición y la cultura española». Palabras de Pedro Sáinz Rodríguez en 1919. BBMP. Año 1919

9 El periódico católico El Debate el 20 de mayo de 1912 insiste en el carácter patriótico y militante de la obra de Don Marcelino que consistió en: «Probar que en España y los Españoles, en lo militar y en lo político, como en lo literario, o son católicos o no son nada, o son medianias, que es peor que no ser nada. Para ésto, de propósito y por directo compuso la Historia de los Heterodoxos, prueba fehaciente de que ningún heterodoxo español sobresalió ni poco ni mucho, ni fue sino uno de los de la reata, y la misma tesis anima a los restantes escritos del coloson. 
problemático, sino mirar al futuro con optimismo. «Sólamente con una firme conciencia española, con una voluntad tensa y unos objetivos claros, nos será posible continuar la marcha. Y lo que en nuestro presente haya habido de vacilaciones, de inseguridad, de pesos muertos, atonía y languidez ha sido por el peso de esas generaciones anteriores más o menos disgregado. Evitemos a todo trance que de nosotros salten astillas que hieran a los españoles a quienes corresponde el futuro" ${ }^{10}$. Para Vicente Palacio Atard, otro colaborador de Arbor, el siglo XIX tejido de guerras civiles, estériles sucesiones de discontinuidad política hasta el 36 , es el resultado natural del Problema de España, fuente a su vez de innumerables problemas prácticos "porque no en vano, dice, gasta un pais durante un siglo sus mejores energías en desangrarse" $" 11$.

El "Problema de España" se suscitó como polémica dentro del Menendezpelayismo en los años 40-50 entre Arbor y los seguidores de Laín y Tovar. Pero era una antigua discusión que se arrastra desde el siglo XVIII, y en el siglo XIX reaparece como polémica de decadencia y de identidad nacional. Tiene su apoyo en La Polémica de la Ciencia Española de 1876, donde se plantea la restauración científica y la inserción de España en la ciencia y cultura europea. Para el Nacional Catolicismo no existen fórmulas «regeneracionistas", "noventaiochistas», "tradicionalistas», " integristas», "vivistas", "krausistas", "casticistas» o «regionalistas". Sólo existen dos fórmulas tajantes: la Católica nacional y la anticatólica liberal. En una misma bolsa histórica se mezclan y pulverizan, todas las tendencias «heréticas" antitradicionalistas, desde el liberalismo de Las Cortes de Cádiz hasta la médula del pensamiento orteguiano. La fórmula de una restauración científica, y del "ser de España» vivista-renacentista y antitomista de Menéndez Pelayo, no se toma en consideración aunque fue compartida por Angel Ganivet en su Ideario, y forma parte de su «independencia» intelectual adoptada en 1944 por Laín Entralgo. Para el Menendezpelayismo más militante, la fórmula predilecta era la de los Heterodoxos: la de una España católica, romana, hispanista, unida contra el hereje, planta exótica sin arraigo en suelo español. El sesgo marcadamente antiliberal y racista de los Heterodoxos es el que se impone, en una discusión donde entran en juego la identidad nacional, un presente o pasado "agónico", y la europeización de España.

Dentro del Menendezpelayismo para los nacionalistas intransigentes como Vigón, el problema de España era su ruptura con la tradición católica

Calvo Serer en “España sin Problema». Arbor 1949, pp. 160-173. pág. 173.

1 Vicente Palacio Atard. Citado por Calvo Serer en “España Sin Problema”. pág. 151. 
reconquistada en el 36, para el grupo de Laín un conflicto agónico entre la hispanidad tradicional y la modernidad europea, y para el Opus Dei de Arbor el problema se resolvía con el lema «españolización en los fines y europeización en los medios". Para Ortega y sus discípulos el problema pasaba por el repudio de la vieja mentalidad religiosa y católica para incorporarse a la Europa laica, tolerante y civil. Cualesquiera que fueran las fórmulas, al Menendezpelayismo lo que menos le interesa como punto de referencia es el Menéndez Pelayo histórico de la Restauración. Sólo rescata de su pasado "la búsqueda de una unidad superior» que prescinda de los histórico. "No nos interesa, opina Pérez Embid en 1949, entretenernos en el coleccionismo de naderias muertas... buscamos de cara a todo el mundo hispánico la vitalidad histórica de aquel maravilloso plano de España que Don Marcelino tenía en la cabeza" ${ }^{12}$. Hurgar como Laín y Tovar en los antagonismos del pasado para reconciliar con él a un Menéndez Pelayo "excéptico", "problemático", "liberal decimonónico", era considerado como traición a la Cruzada Nacional y como elemento de discordia hacia la futura unión de los españoles.

Pero la triste realidad del mito de Menéndez Pelayo es que desde sus orígenes sirvió para mantener divididos a los españoles, y en poder de un catolicismo nacionalista agresivo que lo recicla ininterrumpidamente desde 1912 hasta el 36. ¿Qué se entiende entonces por el "mito" de Menéndez Pelayo? El tema que es de por si complicado se vuelve más confuso dentro del Menendezpelayismo.

Marañón en su obra Menéndez Pelayo desde su Precocidad, indica que los orígenes se encuentran en la juventud prodigiosa de Don Marcelino: "con su precocidad bien pronto se hizo legendario en toda España y aún en el extranjero». Existió también "un fervoroso Menendezpelayismo desde la juventud de Don Marcelino que fue creciendo hasta hoy" ${ }^{13}$.

En efecto, el mito arranca con La Polémica de la Ciencia Española y antes que ella en 1875-76, cuando circulaban por Madrid anécdotas de la asombrosa erudición y memoria del joven Menéndez. Deslumbró a los católicos polemizando con los krausistas. Fray Zeferino González, parco y poco dado a adulaciones personales, quedó impresionado por su madurez de criterio y erudición. En Academias, Ateneos y casas aristocráticas se reunian para oírle. Se modificó una ley para que pudiera ser el académico

12 P. Embid, “Ante la Actualidad..." pág. 153.

13 Gregorio Marañón. Menéndez Pelayo desde su Precocidad, Santander, 1959. págs. 8-9. 
más joven de España. Era para el Catolicismo un "portento providencial», como un David que conquistaba al Goliat de la ciencia positivista. La imagen quedó grabada en lo más hondo de la memoria católica. Existen numerosas cartas de laicos y sacerdotes atemorizados, casi cohibidos ante el caudal de conocimientos, y de aqui las alabanzas extremadas que surgirán respecto a su mérito científico; alabanzas que los neotomistas se ocuparán de atemperar y hasta silenciar en el olvido. Pero no fue la anécdota o lo fabuloso, sino la política la que se ocupará de reciclar el mito de La Ciencia Española y los Heterodoxos. Hay que tener en cuenta que ya en vida de Don Marcelino el catolicismo militante no pierde la oportunidad de manipular la imagen del campeón de la Ciencia Católica, contrarrestando la acción de íntegros y neotomistas que le derriban de este pedestal. El mismo Pidal y Mon que le arrastró hacia la Unión Católica en 1882 , será ambiguo en su discurso necrológico en 1912, relegándole al nivel de un mero creador o artista, excluyéndole de la categoría de filósofo, historiador o teólogo.

Fallecido Don Marcelino el mito permaneció tan complejo como fue el ambiente político religioso en el que se gestó. Los progresistas le insultaban y se lamentaban en 1876, que el "portento" utilizase su erudición de forma poco seria y ofensiva; en 1912 respetan su madurez científica, pero más adelante ante el Nacional Catolicismo callan. Los tomistas resienten en 1876 y 1912, su visión de la restauración científica vivista y le llegan a tildar de hereje; durante el Nacional Catolicismo también callan. Los íntegros que aplaudieron su desenfado en la Ciencia Española, rechazan su apostasia de los Heterodoxos al mestizaje de Pidal, pero el integrismo universal nunca le perdería de vista. Los positivistas del extranjero ponen en 1876 en tela de juicio su erudición, en 1912 hay quienes le respetan y quienes le consideran científicamente "superado". En 1912, para las veladas necrológicas, el mito continuó, y se recicló sobre este complejo montaje de prejuicios entrecruzados. El catolicismo militante enervado por el anticlericalismo de Canalejas, se apresuró a reclamar como "suyo" al autor de los Heterodoxos. Unos meses antes de su muerte, este mismo catolicismo se había movilizado contra el autor de Electra y Casandra, declarando a Don Marcelino como al verdadero representante del «alma nacional» para el premio Nobel. Sin reparar en la amistad que unía a Menéndez Pelayo con Benito Pérez Galdós, se levantan banderas opuestas que continuarán flameando durante el Nacional Catolicismo Menendezpelayista.

La muerte de Don Marcelino el 19 de mayo de 1912, se vivió a símbolo de enfrentamiento entre dos Españas irreconciliables. Sus amigos y autores moderados, deben recordar que el autor de las Estéticas, del Origen de la Novela 
o de los Clásicos Latinos, también era Menéndez Pelayo el erudito católico. Pero al Catolicismo militante no le interesa este aspecto de su obra. Se proclama dueño y heredero absoluto de su pensamiento contra la heterodoxia. "Marcelino es nuestro" ${ }^{14}$ publica la prensa católica de 1912 para acallar el homenaje de otras personalidades, incluyendo amigos y críticos liberales. En este ambiente de recriminaciones, conspiraciones y silencios, se organiza en el teatro Princesa de Madrid, una velada necrológica que reúne a lo más selecto del catolicismo madrileño. Habla el director del periódico católico El Debate, Don Ricardo Herrero, poniendo en marcha el mito patriótico y agresivo "del alma nacional» de Menéndez Pelayo ${ }^{15}$. En la misma velada se leen las cuartillas de Ricardo León «La Escuela del Patriotismo» cargado de resentimiento contra los "bárbaros modernos" que desdeñan la tradición en pro de la europeización. En el ataque caen los del 98, la Institución Libre y Ortega, los mismos adversarios que obsesionarán al Menendezpelayismo franquista. En esta ocasión se dice que hay que enseñarles amor a la patria, a la fe, y a la estirpe, porque "un mal patriota es un traidor a Dios, sus padres y a sí mismo", «la patria temporal es la imagen de la patria eterna... ¿qué mejor escuela de patriotismo que las altas obras de Don Marcelino Menéndez Pelayo? " ${ }^{16}$.

14 Tómese como ejemplo al Correo Catalán del 21 de mayo de 1912 donde se dice que Menéndez Pelayo es «de los católicos y nadie más... de ninguna suerte pueden considerarlo suyo más que los católicos".

15 Ricardo Herrero, director del periódico El Debate organiza una velada el 9 de junio de 1912 en el Teatro Princesa de Madrid, en la que estaban presentes la aristocracia, la banca, el periodismo y las artes. Herrero en su discurso de apertura se muestra pesimista ante la realidad politica de 1912. Ve al pais sumido en un abismo que separa la España antigua y católica de la moderna laica. Frente a estas dos Españas vuelve sus ojos a la obra restauradora de Menéndez Pelayo que "supo mantenerse elevada a regiones fuera del apasionamiento". Balmes y Menéndez Pelayo serán el simbolo de la España católica, representantes del dolor y del alma nacional. En esta velada se palpa la transformación de Menéndez Pelayo del personaje histórico en ideario nacional, militante y patriótico.

16 En esta misma velada Luis Benito y Villanueva, lee las Cuartillas de Ricardo León contra la generación del 98, y la Institución Libre. «Destruir! ¡Barrer! gritan los heterodoxos de nuestro tiempo... ¡Destruir! pero si aqui lo que hace falta es restaurar»... «La solucion, dicen muchos, la solución para España es que los españoles dejen de serlo... jsolución digna de hombres bárbaros y cobardes!". Las obras de Don Marcelino aparecen ya como "evangelio del culto a la Patria". Si se olvidan "entonces si podemos afirmar con estéril, con irreparable pesadumbre, que en él han muerto la tradición española y el gran espiritu de razón". Del Diario Montañés 11 de junio de 1912. En 1912 ya aparecen las obras de Menéndez Pelayo como "evangelio" y los Heterodoxos como su pieza central. Es interesante recordar el relato de José Maria Pemán en "España Sin Problema" de Calvo Serer, acerca de la historia de los Heterodoxos utilizada como evangelio militar. "Gusta de contar José Maria Pemán, que en la mesa de trabajo de Justo San Miguel -uno de los muertos el 10 de agosto- se encontró abierto el Epilogo de los Heterodoxos, su última lectura: y comenta agudamente Pemán que seria dificil encontrar manifiesto alguno que tuviera fuerza tal como para arrastrar a los hombres hasta la muerte al cabo de medio siglo de escrito". Arbor, pág. 161. 
El tradicionalismo español, presente en la velada con el discurso de Vázquez de Mella, anunció que la muerte de Don Marcelino, da comienzo a un tradicionalismo unificador, por encima de partidos, innovador y sin conflictos con el progreso. Este mismo tradicionalismo "universal», que une a los españoles contra el adversario común, es el que servirá al catolicismo de Acción Española, y más tarde al Nacional Catolicismo ${ }^{17}$ de Franco.

El tradicionalismo de Acción Española deja de lado al Carlismo, porque como había dicho Menéndez Pelayo le habian faltado intelectuales y pensadores. El lema de este tradicionalismo será Tradición, Patria, Familia, Orden y Trabajo. En 1956 recordará Jorge Vigón, cómo junto a Ramiro de Maeztu, Pedro Sáinz Rodriguez y otros, se reactualizó la plataforma de Menéndez Pelayo para que se convirtiese en cel alma del tradicionalismo" de Primo de Rivera ${ }^{18}$. Nocedal, Vázquez de Mella y Don Marcelino (tres hombres con adhesiones político-religiosas distintas dentro de la ortodoxia católica de las épocas) aparecen formando un mismo pelotón ideológico. Lo importante es indicar estos momentos históricos en que la persona y obra de Menéndez Pelayo, comienzan a perder su perfil histórico para convertirse en "ideario" nacional contra la heterodoxia. Este proceso que claramente arranca en 1912 se vuelve más complejo al superponerse nuevas ideologías políticas y tradicionalismos partidistas.

Ganada la Guerra, en 1938 se sientan las bases del Nacional Catolicismo en este hilo ininterrumpido de Catolicismo tradicionalista militante. Menéndez Pelayo era el «arquitecto» del nuevo edificio y los Menendezpelayistas sus sustentadores. Se da impulso a una literatura apologética que desborda el "mito» de Menéndez Pelayo en exageradas apreciaciones del maestro que merecen una llamada de atención por parte del director del Boletín de Santander, Don Enrique Sánchez Reyes. Desde un número especial titulado "Menendezpelayismo" anunció que se inicia una segunda etapa del Boletín en $1944^{19}$. Ha llegado el momento de romper

17 El carlismo más progresista de Vázquez de Mella, utiliza a Menéndez Pelayo como tradicionalista español católico, dinámico en su concepción de la tradición. En este discurso se perfila la división entre Mellistas y Jaimistas. Por este motivo se interpreta a Menéndez Pelayo con un tradicionalismo sin "partidos" como "búsqueda del alma nacional y como unión de todos los católicos tradicionalistas". De Menéndez Pelayo se extrae la unidad nacional, el amor por la región y el catolicismo; tres elementos que se pondrán en marcha en sucesivos idearios. Del discurso de Vázquez de Mella se vislumbra un deseo de unión de las derechas contra el enemigo común, en un tono militante que anticipa los hechos de una Guerra Civil.

${ }_{18}$ Véase la obra de Vigón Menéndez Pelayo a los Cien Años, donde se rememora este Menéndezpelayismo falangista. Véase también Acción Española "La Causa del Mal», 1936. págs. 236-237.

19 "Menéndezpelayismo" BBMP. 1944. $2^{\mathrm{a}}$ Epoca, marcando el $32^{\circ}$ aniversario de la muerte de Menéndez Pelayo. 
con el "mito" de Menéndez Pelayo, y de dar a conocer al verdadero hombre detrás del mito. Pero no se trata de un revisionismo histórico auténtico. Pronto quedará claro que lo que entiende Sánchez Reyes por mito es el legendario y anecdótico. El fin de esta nueva campaña era acabar con las "Conspiraciones de silencio" y con las "exageraciones» de fuera y dentro. Menéndez Pelayo, insiste Sánchez Reyes, no fue ni retrógada ni omniscente. Para hacer justicia a su valor científico el Menendezpelayismo debe realizar sus estudios sin partidismos, con mente serena y sin injusticias. Pero este revisionismo tiene otro fin: hacer de su obra "una política salvadora y de altos vuelos que señale rumbos certeros de nuestro porvenir". No es la Restauración, sino otra fabricación nacionalista la que se impone. En línea con la desarrollada por Arbor "de honda raíz española, alejada de toda política de partido", este nuevo enfoque no implica un acercamiento o reconciliación con la España de los vencidos. Lo que seguirá, serán «actualizaciones", "vindicaciones" de Menéndez Pelayo desde trincheras opuestas o divergentes de tono agresivo hacia posibles aperturas en dirección a un catolicismo orteguiano.

El Menendezpelayismo desde Santander, se integra a la labor cultural del Consejo de Investigaciones Científicas, con un "apoliticismo" cuya meta era destruir la obra científica de la Institución Libre de Enseñanza. En el proceso de desmitificación no se busca la verdad histórica sino "superarla" como pasado agónico. Al volverse la historia "trascendente", en cierto modo se la neutraliza, y esto mismo ocurre con la persona de Menéndez Pelayo. Sus ideales, desenganchados de su contexto histórico, fácilmente se elevan a la categoría de ideario nacional.

Existen ciertos resortes psicológicos o "tácticos" que el Menéndezpelayismo utiliza y que convendria destacar para comprender la sutileza de los argumentos, antes de mencionar a autores determinados. En general la critica menéndezpelayista se empeña en destacar el antikrausismo de Don Marcelino con el cual se desprestigia a la Institución Libre, esa gran obsesión del régimen franquista, considerada como causa de todos los males nacionales que desmeduló la patria y le desvió del curso de la historia. En el debate interno se deja de lado la doble polémica con krausistas y tomistas de la Polémica de la Ciencia Española, minimizando como «rencillas domésticas» el confrontamiento con los ortodoxos y sobredimensionando la de los "heterodoxos" krausistas. Había muchos menéndezpelayistas que niegan la doble polémica de La Ciencia Española que analizada objetivamente resulta más agresiva y devastadora desde el sector tomista y tan voluminosa como el material krausista. El gran tabú del Menendezpelayismo, su gran silencio, serán precisamente las disidencias con el tomismo, integrismo y tradicionalismo francés, tres piezas 
clave de la heterodoxia ultramontana de Vaticano I. Consecuentemente el Menendezpelayismo no querrá admitir el progresivo desarrollo y madurez científica que irá adquiriendo la obra de Don Marcelino. Sánchez Reyes en su última Biografía Crítica y documental de Marcelino Menéndez Pelayo (1974) (SANCHEZ REYES fue autor de tres biografías) ${ }^{20}$ se niega a aceptar este hecho alegando que Don Marcelino de las Estéticas es el mismo católico inflexible de los Heterodoxos. Esto, en un autor que conocía las polémicas internas, es mera tozudez ideológica. Por lo general el Menendezpelayismo comparte con él un deliberado desconocimiento de las Estéticas y de las obras de sabor clasicista, donde el confrontamiento de Don Marcelino con la ortodoxia católica es más notoria.

Por temor a encontrar demasiadas contradicciones que ponían al descubierto la no demasiada clara y sencilla ortodoxia de Menéndez Pelayo, el Menendezpelayismo ofrece a la juventud su pensamiento "depurado" en textos como los Textos sobre España de Florentino Pérez Embid ${ }^{21}, \mathrm{y}$ Antologías Generales como la de J.M. Sánchez de Muniain. En ésta última, el prólogo del obispo de Málaga, Monseñor Angel Herrera Oria anunció que la historia pasada de Menéndez Pelayo no interesa ni lo que la historia deja en sus libros. Lo importante es el "cristiano ejemplo que de ella se hizo" "22. La Antología publicada por el Consejo de Investigaciones Científicas para el centenario de 1956, no tiene intención de crear una escuela ni científica ni objetiva. Es una ambigua recopilación de textos orgánicos, donde se incluyen algunos epistolarios del poligrafo, pero con "criterio constructivo", y sin banderas políticas. Este vade mecum antológico, que dice despejar el mito de Don Marcelino, corrige exageraciones y despeja prejuicios en sentido "nacionalista", sin referencia a un contexto histórico adecuado, y hasta prescindiendo de la misma historia. Lo que se quiere fomentar es la imagen de un catolicismo "eterno", sin fisuras, en un bloque unido y compacto de la fe española contra una "minoria»

20 E. Sánchez Reyes. Biografia del último de nuestros humanistas (Biografía critica y documental de D. Marcelino Menéndez Pelayo). Santander, 1956; Menéndez Pelayo. Su época. Su obra literaria. Estudios de las ldeas Estéticas en España. Ed. Teide. Barcelona, 1962; Biografia critica y documental de Marcelino Menéndez Pelayo, $3^{a}$ Ed. aumentada y corregida. Ed. Nacional de las Obras Completas de Menéndez Pelayo, Santander, Aldus, 1974. Véase también su artículo "La Prensa y el Brindis de Menéndez Pelayo" BBMP, XV-pp. 210-215; 312-317.

21 Florentino Pérez Embid. Textos sobre España, Rialp, Madrid 1955. Libro dedicado a Rafael Calvo Serer. En esta obra además de reivindicar la "conciencia nacional» en Menéndez Pelayo, y que sus ideas son la base de de "nuestra cultura actual», se censura a la España nueva "hija de Giner», y a la obra de Pierre Jobit sobre los krausistas españoles. Culpa Pérez Embid a la Institución Libre de haber "prolongado la vigencia de una conciencia nacional escondida y de una versión problematizada del sentido de nuestra historia”. pág. 75.

22 J.M. Sánchez Muniain. Antologia General de Menéndez Pelayo, CSIC; BAC. Madrid, 1956. 
heterodoxa, vencida por la Ciencia de Menéndez Pelayo y el brazo armado del Caudillo.

Ante la realidad histórica de los textos de Menéndez Pelayo, el Menendezpelayismo se confecciona fórmulas escapistas para explicar lo que no se quiere ver. Se le resta importancia a las polémicas con la ortodoxia católica, minimizando sus efectos y el valor intelectual de sus adversarios tomistas que atacan a Don Marcelino por cerrazón de escuela, y no en nombre de la renovación escolástica impuesta desde Roma. A Don Marcelino se le desengancha de su problemática católica, creando la imagen de un ser "superior", cuyo espíritu vuela libre por encima de estas pequeñeces domésticas de mentes mezquinas. En cuanto a su tradicionalismo católico, tema complejo durante la Restauración donde íntegros, carlistas y mestizos se disputaban el título, el Menendezpelayismo utilizará la fórmula de un tradicionalismo español, católico, unido, trascendental y centralizador, que se dice fue el de Menéndez Pelayo. Aunque existe evidencia de un "escepticismo" por parte del polígrafo respecto a ciertas glorias de la tradición católica de España ${ }^{23}$.

Otro dilema era mantener la imagen de un Menéndez Pelayo sin «lunares", la del perfecto intelectual católico, ortodoxo de una pieza. Pero a la hora de desentrañar su liberalismo conservador canovista, su clasicismo riesgoso, su hamiltonianismo, hegelianismo y eclecticismo de "tejas abajo», los críticos se encuentran con «problemas». Para Laín Entralgo estos serán restos de "modernidad", para el Menendezpelayismo intolerante "debilidades humanistas", cuestiones "accidentales" que no alteran su impecable ortodoxia, pero que dejan sin resolver el problema de su ortodoxia intelectual.

Del grupo Menendezpelayista intolerante, se destaca la obra de Jorge Vigón, quien para el centenario de Menéndez Pelayo publica un libro Menéndez Pelayo a los Cien Años ${ }^{24}$, tan vigoroso y militante como en sus épocas de Acción Española. Recuerda en él a sus colegas de campaña, sobre todo a Ramiro de Maeztu y a los mártires del 36, quienes derramaron su sangre por defender la España de Menéndez Pelayo. «El 18 de julio, insiste Vigón, se había montado en gran parte sobre una estructura doctrinal cuya inspiración venía de su obra y notablemente ésta era

${ }^{23}$ Véase la discusión entre J. Cantera y Orive "Las tradiciones españolas en Menéndez Pelayo" y Enrique Sánchez Reyes "Unas apostillas al articulo sobre tradiciones españolas". BBMP. XXXII, 1957. págs. 131-144; 145-152.

${ }^{24}$ Menéndez Pelayo a los Cien Años. Ed. Nacional Hombres de Actualidad, Madrid, 1957. pág. 16. 
para algunos una realidad embarazosa muy dificil de eludir... Porque el 18 de julio es ante todo una grave lección que algunos parecen resueltos a olvidar". Los algunos son los heterodoxos de "h» minúscula a quienes Vigón les recuerda que "el liberalismo sigue siendo incompatible con los principios que salimos a defender un 18 de julio". Al igual que los integristas de antaño, este sector intransigente "deslinda los campos» (frase favorita de los íntegros decimonónicos) para que no se contaminen unos con otros y se mantenga intacta la España de Vencedores y Vencidos. Les preocupan más los heterodoxos de "h" minúscula, que los de "h" mayúscula. Entre los minúsculos están Laín, Tovar, Dámaso Alonso, etc. Vigón advierte que los que intentan dialogar con la España heterodoxa son infieles a la memoria de Maeztu y a la persona de Menéndez Pelayo, porque sigue vigente el autor de los Heterodoxos y los que le «liberalizan" desvian de su natural cauce el sentido de su obra. En el mismo estilo de la apologética íntegra decimonónica, Vigón denuncia el lenguaje lleno de matices y sutilezas que emplean los de "h" minúscula, porque éste no concuerda con el severo texto del católico a machamartillo. Advierte al lector incauto de las trampas del lenguaje «tolerante", que emplea palabras como "caridad", "madurez", "comprensión", terminología que azucara el pensamiento de quien hasta en sus últimos días fue católico inflexible. Vigón se opone rotundamente a "la claudicante teoría de la evolución espiritual de Don Marcelino", teoria "puesta al servicio de un empeño decidido de estampillardo como liberal». No le acepta a Tovar que se le denomina "neoliberal» o "postliberal» o "buen liberal decimonónico". Vigón mantiene que este título no se puede aplicar a Menéndez Pelayo porque no estuvo nunca a la altura de un Sagasta, Cánovas, Azaña y otros políticos liberales, implícitamente condenados en el Syllabus de 1864. "Para el que no hubiera encontrado allí un hueco, añade Vigón, hubiese sido para Don Marcelino". Atribuye a "debilidades humanas" su canovismo, maurismo, su amistad con Galdós y sus discrepancias con el neotomismo, rasgos "accidentales" que no alteran el contenido antiliberal de su obra. Vigón increpa a Dámaso Alonso y a Tovar de querer deformar y desvirtuar simultáneamente a Menéndez Pelayo, a Acción Española y a la Cruzada Nacional.

El ambiente del Centenario tenia irritado a los críticos intolerantes del Menendezpelayismo. La muerte de Ortega y Gasset en 1955 había actuado como detonante hacia una apertura no deseada por los vencedores del 36. En lenguaje que recuerda al de Sardá y Salvany o los Nocedales Vigón pide al Menendezpelayismo una cautelosa discriminación: "conviene precisar y deslindar las escuelas y tendencias filosófico-religiosas a que el autor pertenece, único método de apreciar rectamente los rumbos 
que en la política ha seguido". En este clima de recriminaciones personales, sus adversarios «liberaloides» acusan a Vigón de "banderizo»; de querer restaurar la bandera de la Falange en nombre de Menéndez Pelayo. Les responde Vigón que el signo es secundario: lo que importa es la empresa cultural de signo católico que restauró el sentido nacional cristiano, perdido antes del 36. Liberalizar a Don Marcelino significaba destruir esta empresa, que si bien tuvo su «banderín de política pequeña» en falange, fue ante todo un "gesto de valor universal". Vigón no encubre el uso político de Menéndez Pelayo por parte de los falangistas, y el hecho que Acción Española apadrinó su obra «si una política pide, ante todo, un sistema de ideas, una visión clara del pasado y un proyecto concreto del futuro, probablemente no había un sólo español que pueda ofrecer una plataforma tan amplia y tan sólida para instalar en ella una política nacional». Pero lo que más le preocupa es que la juventud, a pesar del Menendezpelayismo oficial se haya volcado hacia Unamuno, Ortega, Menéndez Pidal, etc... dejando en el olvido a Menéndez Pelayo. La culpa, insiste Vigón, es la de los críticos liberaloides que le niegan la validez científica y filosófica que le otorgan a otros, sobre todo a Ortega, un español que desde 1914 desvió a las grandes masas de la tradición católica defendida en los Heterodoxos.

Esta polémica interna del Menendezpelayismo revela que hay dentro tendencias "actualizadoras" que promulgan una imagen más "comprensiva» del poligrafo. Pero no todas vienen por parte del acomodaticio. Existe un intento por parte del integrismo nacionalista de restaurar la figura de Don Marcelino como justificación histórica de un integrismo «progresista". En este aspecto es interesante la obra del escritor catalán $M$. Brunsó y Martirian "España en el diálogo al integrismo crimen de lesa Patria y signo y azote de nuestro tiempo" ${ }^{25}$. No es obra estrictamente Menendezpelayista pero si de historiografía apologética en defensa del integrismo tradicionalista durante el Concilio Vaticano II. El concilio tenia encrespado al Nacional Catolicismo que se defendía contra los nuevos vientos que soplaban (como en tiempos de León XIII) con una visión antisecularizadora, y antiliberal de la historia de España. Brunsó como Vigón mantiene vivo el recuerdo de la Cruzada Nacional que había vencido al comunismo y a la heterodoxia religiosa, pero ante una imagen "peyorativa» del integrismo, Brunsó argumenta que fue una fuerza «positiva» en la sociedad. Pone como ejemplo a Menéndez Pelayo, católico "íntegro» y

25 M. Brunsó y Martirian, España en el diálogo o el anti-integrismo, crimen de lesa patria. signo y azote de nuestro tiempo. Barcelona, Colección España en el diálogo, 1966. 
"tradicionalista", pero amante del progreso y de las doctrinas de la Iglesia. Es el "ejemplo mayor de la forma en que el intelectual cristiano debe conciliar su fe y libertad, fidelidad e independencia, amor y condenación, refutación y comprensión, polémica y caridad" Don Marcelino aparece como católico "comprensivo" pero no dentro de la corriente liberal secularizadora dispuesta a transigir con el error, ya que con ella fue inflexible. Sin embargo Brunsó percibe más que Vigón los cambios históricos del integrismo del XIX al XX. A Don Marcelino Brunsó le separa del integrismo nocedalista, de cuestiones político religiosas como la carlista, ya rezagada, aunque le sigue vinculando con los principios antiliberales «trascendentales" de "El liberalismo es Pecado» de Sardá y Salvany. Este integrismo dirá, sigue pujante y "actual», a pesar del Concilio Vaticano II. También sigue vigente el tradicionalismo íntegro de los Heterodoxos, obra que forma, en su opinión, un cuerpo común de doctrinas con el Syllabus, el Liberalismo es Pecado y las Encíclicas Lamentabili y Pascendi Gregis de Pío X.

A la hora de definir el tradicionalismo de Don Marcelino, Brunsó, como buen catalán, le vincula con el de los dos españoles insignes - Vázquez de Mella y el obispo de Vich Torras y Bages. Ambos reaparecen como tradicionalistas progresistas, y a Torras y Bages le atribuye un escolaticismo y regionalismo nacionalista. Como catalanista era imprescindible encontrar una fórmula integro-tradicionalista --progresista- pero dentro de la unidad nacional franquista. Don Marcelino parece encajar en este proyecto de patria chica dentro de una patria grande, con un tradicionalismo respetuoso de las autonomias, pero no de un separatismo suicida, como lo da a entender en el Congreso de Balmes de 1910.

No es únicamente el ambiente del Concilio lo que tiene preocupado a Brunsó. También «el concierto internacional» influye hacia aperturas liberales. "Con mayor brio Norteamérica parece mirarnos con sonrisa de amistad y nuestros contactos con Francia son más frecuentes". Este clima da pie a que los "católicos de gauche», Laín Entralgo, Aranguren y Julián Marías, entre otros, parloteen en las universidades y alienten el silencio y la "muda soberbia" de los institucionistas respecto a Don Marcelino. Aunque no comparte la intransigencia vociterante, pero viva y caliente, del sector más cerrado y "de corto alcance», tampoco aplaude a las nuevas "élites" que desprecian al integrismo, y cuyos circulos intelectuales van en aumento.

La obra que quizás sintetiza mejor este ambiente de inseguridad interna, y que reúne todos los prejuicios de la derecha, es el pomposo libro titulado "Un arbitrario texto orteguiano. El esfuerzo medular del krausismo frente a la obra gigantesca de Menéndez Pelayo", cuyo autor es un 
Presbítero, profesor de Oviedo Don Cesario Rodríguez y García Laredo ${ }^{26}$. Este libro es un manifiesto triunfalista del espíritu de los vencedores que en 1961 no consideran superada la victoria. El autor recuerda que una "minoría disidente" fue vencida en 1936, como en tiempos de Menéndez Pelayo en 1876. Lo que llama la atención es su definición de dicha «minoría" en la que incluye a generaciones de españoles que abarcan desde los jansenistas, regalistas, volterianos, enciclopedistas, masones, y afrancesados del siglo XVIII, a los liberales doceañistas, moderados, progresistas, demócratas, krausistas, libertino-institucionalistas, europeizantes, separatistas, frente populista, republicanos y rojos del siglo XIX y XX. Dos hombres vencieron a esta "minoría": Menéndez Pelayo con su ciencia, el caudillo con su brazo armado. Sigue vigente el tabú contra la Institución Libre, causa de todos los males y de la educación diabólica que desmeduló a la patria. Hay que volver a extirparla (como si no se hubieses intentado desde el 38), y el antídoto sigue siendo Menéndez Pelayo. El libro es un furibundo ataque contra Ortega, y como lo sugiere el título, una censura del sector "comprensivo" que coquetea con él. Para el autor «los campos están deslindados" y no pueden existir posturas intermedias. Nuevamente advierte contra el lenguaje tolerante y acomodaticio de los modernos menéndezpelayistas y se ofrece una significativa bibliografía de quienes en 1961 son de "sana lectura". De ella se excluye al sector "liberaloide" y a los llamados "nietos del 98". Entre los sanos estarán la Antología General de José María Sánchez Muniain, la revista Arbor y sus colaboradores del Opus Dei; las biografias de Sánchez Reyes, la bibliografía de José Simón Díaz y otros autores claves del Nacional Catolicismo integrista.

Es obvio que como en tiempos de Nocedal, los vencedores no ceden terreno ante la mestizería contemporánea. A nivel historiográfico en estas obras aparecen en una misma bolsa y bandera ideológica personalidades históricamente dispares como Balmes, Donoso, Aparisi y Guijarro, Sardá y Salvany, Vázquez de Mella, Menéndez Pelayo, José Antonio Primo de Rivera, en una línea recta de pensamiento tradicional que desemboca en el cauce natural de la España del caudillo, con el enemigo común acechando desde fuera, sobre todo contra Menéndez Pelayo.

Se nota también el esfuerzo de este tipo de literatura por "vindicar» el honor científico y literario de Menéndez Pelayo, puesto en tela de juicio por

26 Cesáreo Rodriguez y Garcia Laredo «Un Arbitrario Texto Orteguiano. El esfuerzo medular del krausismo frente a la obra gigantesca de Menéndez Pelayo". Oviedo, 1961. 
los «hipercriticos" que se niegan a considerarle filósofo, teólogo, historiador e hispanista. Don Cesáreo Rodríguez responde que Don Marcelino fue "insigne pedagogo universitario", "gran europeo pero no europeizante", "apologista tradicional español», "profeta de los destinos de la patria", "maetro eximio y excelente", "teólogo consumado", "descubridor del parnaso americano", etc... Lo que no le concede es el título de liberal decimonónico, acercándole más hacia el integrismo de Sardá y Salvany porque ambos odiaban el error liberal. En los argumentos se confunden las reflexiones del autor sobre la vida del polígrafo con la convicción de que los vencedores siguen venciendo sobre la "minoria" heterodoxa, y añade: "Sí, porque tenemos la razón, porque sabemos defenderla, porque también sabemos que no nos ha de faltar la ayuda de Dios, que nunca abandcna a esta España tan suya».

Paralélamente a este tipo de apologética "actualizadora" de Menéndez Pelayo, un segundo grupo de intelectuales de la revista Arbor, proponen matices más optimistas pero igualmente antiliberales. Florentino Pérez Embid y Rafael Calvo Serer, también se sienten herederos del alma nacional de Menéndez Pelayo, pero en tono menos defensivo y más europeista. Arbor se ocupa de promover un desarrollismo tradicionalista pero dirigido contra los institucionalistas. El Consejo que había suprimido la obra de la Institución, confiscado sus bienes, y ocupado el lugar de la Junta para Ampliación de Estudios, no pregonaba su retorno a la escera política o educativa. Pérez Embid en los Textos sobre España lo expresa claramente. Pero ante la citada polémica sobre "España como problen a" la atención se centra hacia el enemigo interno. En esta discusión se confunden Menéndez Pelayo como intelectual católico y el pasado agónico que los «nietos del 98» quieren desenterrar. En esta dirección había escrito Lain Entralgo su libro sobre Menéndez Pelayo. Historia de sus problemas inte. lectuales ${ }^{27}$ donde da a entender que Don Marcelino era representante de una España agónica, melancólica, todavía problematizada. Esta misma teoría la amplía Lain en otro trabajo suyo sobre La España como Problema, publicada en el Semanario del problema hispanoamericano, Madrid 1949. En esta ocasión, Laín propone la reconciliación de las dos españas, y argumenta que la misión de los intelectuales católicos es la de unirse por medio de la imagen de un Menéndez Pelayo agónico. En su artículo "Ante la Actualidad del Problema de España" le responde Pérez Embid que si existió una España problemática, con un complejo de inferioridad ante la

27 Pedro Laín Entralgo, Menéndez Pelayo. Historia de sus Problemas Intelectuales, Instituto de Estudios Politicos, Madrid, 1944. Idem. Buenos Aires, Espasa Calpe, 1952. Colección Austral. 
modernidad europea descristianizada, ésta habia sido «superada» en el 36. Durante su vida Don Marcelino habia trabajado para sobreponerse a la postración, y construir la única España posible, la de Franco, católica, unida y con una misión cristiana para el resto de Europa. Insiste en que la guerra civil habia puesto fin a los problemas y que se abría un nuevo futuro, la nueva realización de España con que había soñado Menéndez Pelayo. A los jóvenes del Consejo les toca continuar su labor interpretando correctamente su pensamiento, y no por medio de la "caricatura" fabricada por los nietos del 98, de un Pelayo agónico. "Estamos en verdad muy lejos de aquella lacerante antinomia de españolización y europeización que fue tan cara a los hombres del 98 y de un modo o de otro ha seguido preocupando o confundiendo a muchos de sus sucesores" (Arbor, 159). Las nuevas generaciones deben, como Don Marcelino, rescatar a los españoles de su postración y sobreponerse a las dificultades, para construir con patriotismo sano y crítico «los valores espirituales» de esa España que intentó sin éxito destruir el comunismo y el liberalismo secularizador.

Rafael Calvo Serer impugna desde Arbor en su artículo "España Sin Problema", al segundo contrincante de los «hipercríticos": Antonio Tovar autor de Menéndez Pelayo y la Conciencia Española ${ }^{28}$. Tovar siguiendo la línea de Laín, selecciona extractos de la obra de Don Marcelino donde aparece "problematizado" y como "liberal dicimonónico". Su versión de España no será ni optimista, ni constructiva, ni camino a un futuro desarrollo como pregonaba Arbor. Era una España como la de la Restauración, y como la concebía la generación crítica del 98 , una nación amarga, con el mismo desaliento que había experimentado en vida Don Marcelino. Tovar propone una "actualización" de Menéndez Pelayo tomando conciencia de la problemática generacional del 98 que todavía seguía en pie.

A los jóvenes de Arbor no les cayó bien esta definición noventaiochista de Menéndez Pelayo. Hasta cierto punto Calvo Serer está dispuesto a conceder que en Don Marcelino hubo un rasgo de desaliento y agotamiento de espíritu. Pero le recuerda que su fe inamovible en la validez de sus ideas y de la única España posible, convergen con la estimación actual, optimista y esperanzadora del futuro de España con que sueña el Opus Dei. No niega tampoco que Menéndez Pelayo fuese simbolo de unidad, como proponian Laín y Tovar, pero de una unidad bien entendida, homogénea y monolítica como la del 39, y desde luego sin heterodoxos. 
El tema de la unidad de los españoles en 1949 era tan conflictivo como en tiempos de la Restauración. Arbor la entiende a la luz del documento sobre la Educación Nacional del 38. Sin concesiones a la España de los vencidos; unidad que significaba nivelación, uniformidad y sumisión a la Iglesia y Estado. La imagen de una España unida por Menéndez Pelayo y Benito Pérez Galdós les disgustaba y era impensable en el ambiente de la postguerra.

En cuanto al título de "liberal decimonónico" de Tovar, otro punto controvertible de las polémicas internas, Calvo Serer responde que si Don Marcelino fue liberal en sentido canovista o maurista, esto fue algo "accidental"; "posibilidades politicas" que nunca se tradujeron en actos porque estaban en contradicción con su espíritu católico. Respecto a la madurez y evolución de Menéndez Pelayo, le responde a Tovar que el Menéndez Pelayo de los Heterodoxos es el mismo de las Estéticas y que no es signo de flexibilidad y liberalismo una cierta "tolerancia" que se desarrolla en esta obra donde Menéndez Pelayo se define en estética, hegeliano. La fe de Don Marcelino, insiste Calvo Serer es fecunda y comprensiva como investigador, pero no es una retractación de su postura juvenil. Llamarle como Tovar, "buen liberal decimonónico a la inglesa" es mucho presumir. Se pregunta Calvo Serer "¿cómo podrá configurarse esa calificación de liberal decimonónico con el reconocimiento que Tovar hace de sus ideas de católico ultramontano?» (pág. 170).

El presunto regionalismo de Menéndez Pelayo, otro punto candente para la centralización férrea del Movimiento Nacionalista, lo resuelve Calvo Serer argumentando que su aversión era hacia el centralismo afrancesado de los Borbones, y no al de Franco, patria diversa pero unida. En cuanto a la europeización las ideas de Don Marcelino concuerdan con las del Opus Dei; españolización en los fines y europeización en los medios.

Hay demasiada propaganda nacionalista en los escritores de Arbor para resolver verdades históricas en la vida de Menéndez Pelayo. Con frecuencia los argumentos se mezclan con recriminaciones personales, acusaciones de infidelidad e ingratitud a Menéndez Pelayo de quienes sostienen que era personaje contradictorio, hombre de "lunares" y conflictos. Para los defensores de Arbor a M. Pelayo se le empequeñece resaltando sus contradicciones. Tovar y Laín son entonces cómplices de la conspiración de silencio contra Menéndez Pelayo al describirle como imperfecto y problemático.

El tercer grupo, el de los "hipercríticos", cuya figura lidera Laín, si bien no ofrece una versión rectilínea santurrona $u$ optimista de Menéndez Pelayo, tampoco resuelve el problema histórico. Su versión 
será igualmente ambigua. A Laín le pertenece la iniciativa de haber sido el primero en sugerir que Menéndez Pelayo tenía problemas y que éstos provenian en gran parte del catolicismo de su época. De Laín es la célebre frase citada con frecuencia por críticos liberales que no se animan a entrar en el delicado asunto de la ortodoxia del polígrafo: "La intención permanente de Menéndez Pelayo desde su aparición dentro del horizonte católico español, fue superar católica, creadora y científicamente dentro de una caliente fidelidad a Cristo y a la historia de España, la cruenta e inútil antinomia de la España del siglo XIX» ${ }^{29}$.

El texto de Lain deja entrever lo que en 1944 era atrevimiento y osadía sugerir, sus conflictos con la ortodoxia religiosa. Pero lo más delicado era definir y desmenuzar históricamente a ese catolicismo ortodoxo. Para no escandalizar al lector, Laín comienza cautelosamente declarando que Menéndez Pelayo murió y vivió como católico, incluso como un santo. Confirmada la pulcra catolicidad de Menéndez Pelayo con frases poéticas, piadosamente elocuentes para halagar al lector franquista, Lain procede a preguntar ¿Cómo era católico Menéndez Pelayo y en qué sentido debe interpretarse el catolicismo de su época? Con cautela emprende su análisis anunciando que lo hará sin "tocar problemas tocantes a la vida que suele llamarse privada", y siguiendo "un modo singular» de ser católico. Con frases ambiguas como "su modo histórico de serlo" o "el tipo histórico de su catolicidad», Laín evade al catolicismo de la Restauración. Levanta un esquema de "tipos históricos" que buscan un "modo" de ser católico en la historia universal. Encuentra tres tipos: los antiguos o quasi paganos, los medievalistas y los renacentistas. Entre los medievalistas figuran los escolásticos y de este grupo excluye a Menéndez Pelayo. A Don Marcelino le agrupa entre los renacentistas, católicos modernos de fe religiosa y crítica, de pensamiento independiente. En esta categoría se enrola a sí mismo. Aclara Laín que esta independencia renacentista no es la de los protestantes, emancipados de Dios y la autoridad eclesiástica. La suya es una independencia madura, distinta de la fe mezquina y estrecha medievalista, la misma fe de Luis Vives y de los filósofos del XVI.

Este enfoque historicista de Laín no resuelve el problema de ser católico bajo el Concilio Vaticano I, donde las independencias, incluida la renacentista eran mal vistas. El Renacimiento sigue siendo válvula de escape, evasión histórica del catolicismo integrista, en ambos siglos,

29 Esta frase de Lain, pág. 122, recorre muchos trabajos que siguen su punto de vista, pero nadie desmenuza el fondo político-religioso que se esconde detrás de este ambiguo texto. 
para Menéndez Pelayo del neoultramontano del siglo XIX, para Laín del Nacional Catolicismo del XX. Lo importante es destacar que Laín, el elaborar el delicado tema de la ortodoxia humanista de Menéndez Pelayo, "de tejas abajo" y "sano escepticismo", busca para sí mismo un hueco en la historia, y utiliza el drama de Menédez Pelayo para expresarlo. Con frecuencia Laín se escapa por la tangente histórica "universal», absolviendo a Menéndez Pelayo y a sí mismo, de ciertas responsabilidades intelectuales. Argumenta que Don Marcelino no fue ni teólogo, ni filósofo, ni místico, ni enfrentó su fe como problema de dogma de fe. Por lo tanto como católico seglar, era libre para pensar como humanista e historiador. Lain asume que Menéndez Pelayo se mantuvo al margen de discusiones teológicas, filosóficas, doctrinales y misticas, afirmación que no comparte el Menendezpelayismo intolerante, y que tampoco tiene consistencia histórica. Al mencionar los choques con el integrismo de Nocedal o Fonseca prefiere o restar importancia al adversario, o dejar de lado "los motivos y los incidentes concretos de tal ruptura ${ }^{30}$. La causa eficiente no debe ser buscada en la superficie, sino en las raíces del alma". Recurre a fórmulas vagas como «el concordismo» para sustituir al liberalismo, vivismo, catolicismo y nacionalismo de Menéndez Pelayo. Se supone también que era un ser "superior" a sus adversarios, y que vivió al margen de semejantes "trivialidades" internas. Laín, como los grupos anteriores, sigue reciclando un "mito» falso, para evadir lo que no se permitía incluir en una biografía del polígrafo.

El libro de Laín, marca sin embargo un cambio de rumbo, y a partir de su libro los menéndezpelayistas se dividen en los que ven "lunares" y los que los niegan. Desde 1944 lo que se publica será a favor o en contra de la tesis de Laín y su versión de los problemas intelectuales de Menéndez Pelayo. Pero para lograrlo hubo de disfrazar el tema con un análisis «psicológico" poco esclarecedor, abriendo nuevos horizontes en el mito ya existente.

En los ocho años que separan el libro de Laín del Centenario, las polémicas internas se multiplican y aumentan de tono agresivo. El

30 Esta cita de Lain pone de manifiesto su absoluta evasión del tema: “Dejemos a un lado los motivos y los incidentes concretos de tal ruptura. La causa eficiente no debe ser buscada en la superficie, sino en las raices del alma. Los que ya conocen de Don Marcelino mente histórica, índole de su actitud religiosa, voluntad de superar la polémica noventaiochista, etc. habian de apartarle casi forzosamente del sesgo que por entonces tenía la politica integrista e incluso la tradicionalista». pág. 187. 
Centenario, sirve para glorificar al caudillo, tanto o más que a Menéndez Pelayo. En la prensa gallega, por ejemplo, se entrecruzan las imágenes. Menéndez Pelayo pasa a ser "el Petrus de nuestra Iglesia literaria"; su obra «La Covadonga de nuestra reconquista espiritual», y su persona, genio de la raza y "capitán general del espíritu". Cuando el caudillo rinde honores militares y de capitán general en la tumba de Menéndez Pelayo, al trasladar sus restos a la Catedral de Santander, se dice que "Don Marcelino Menéndez y Pelayo puso su pluma en el mismo altar donde el caudillo de España ha colocado su espada salvadora" ${ }^{31}$. Iglesia y militares seguían en 1956 tan unidos en sus campañas contra el comunismo y la Institución Libre como en el 36. En sus Declaraciones sobre la misión de los intelectuales católicos, los obispos metropolitanos advierten a los españoles de las peligrosas desviaciones del criterio ortodoxo en materia filosófica y cultural ${ }^{32}$. El deber del intelectual era ser fiel a las enseñanzas de la Iglesia y a su misión de propagar la cultura española de signo católico. Menéndez Pelayo era el modelo inquebrantable de fidelidad a la Iglesia, grande historiador, que demostró que en España nunca floreció la heterodoxia.

La pastoral de los metropolitanos describe un ambiente intelectual rodeado de tentaciones dentro y fuera del catolicismo y en el Menendezpelayismo proliferan las "vindicaciones" de Don Marcelino de los prejuicios de la izquierda, pero también del silencio de los "suyos". Rafael García de Castro, obispo de Granada, en un artículo sobre "La rectitud de criterio de Menéndez Pelayo" ${ }^{33}$ publicado en el Boletín de Santander, insinúa que la conspiración de silencio contra Menéndez Pelayo es doble: "Tema pues, delicado y apasionante más para estudiarlo con delicadeza y sin pasión, a la luz serena de la investigación histórica y literaria". El obispo es consciente que el neotomismo y las órdenes religiosas le han negado valor científico a su obra «por no haberse visto sentado en las aulas de las universidades eclesiásticas ni repasando página a página libros de texto» (pág. 15).

En efecto los redactores de la Biblioteca de Teólogos Españoles dirigida por dominicos, no le conceden a Menéndez Pelayo un lugar ni como

31 La prensa gallega casi unánimemente expresó estos sentimientos que nosotros hemos tomado de El ldeal Gallego, año 1956.

32 Véase Documentos Colectivos del Episcopado Español 1870-1974. B.A.C. Madrid, 1974, págs. 286-291

33 Rafael Garcia y Garcia de Castro, "La Rectitud de criterio de Menéndez Pelayo", BBMP. XXXII, 1956. pp. 9-29 
filósofo, historiador o teólogo ${ }^{34}$. El jesuíta Padre Iriarte ${ }^{35}$ tampoco le incluye entre los "filósofos» contemporáneos y sólamente lo rescata Adolfo Muñoz Alonso en la Revista de Filosofía "como filósofo estricto" ${ }^{36}$. Entre los escritores que «obedeciendo a razones de secta... o ataduras de escuela" desvalorizan a Menéndez Pelayo, se encuentran Eugenio D' Ors, Marcial Solana, el Padre Iriarte, el dominico Luis Alonso Getino, Mario Menéndez Bejarano, Julián Marías. Le defienden como filósofo consumado Salvador de Bonis, José Beralú, Luis Gironella. Esta era una vieja polémica que se arrastraba desde la primera biografía en 1911 de Bonilla y San Martín, y en el artículo de López Arana en el Boletín de 1919, donde Don Marcelino no aparece como «propiamente filósofo" ${ }^{37}$. Pero en el Centenario esta cuestión reaparece como una reivindicación nacionalista.

En cuanto a Menéndez Pelayo como historiador Palacio Atard y Luciano Calzada ${ }^{38}$, lo rescatan como historiador "actual» en las páginas de Arbor. Pero este revisionismo histórico tampoco está dispuesto a olvidar la Guerra Civil, ni al autor de Heterodoxos. La actualización de Don Marcelino como historiador incluye un plan para integrar a España en Europa, romper el excesivo casticismo, y para que España pudiese ejercer

34 Es interesante indicar la objetividad con que el historiador $V$. Beltrán de Heredia en su colección de artículos sobre Historia de la Teologia Española, Salamanca, 1971. Tomo IV, juzga la obra de Menéndez Pelayo "En una obra de especialización deja mucho que desear» (pág. 177). Pero no lo considera como un erudito improvisado sino sesudo y responsable. Le corrige en temas controvertibles con el $P$. Fonseca, pero le reconoce la cerrazón de las universidades españolas a raíz de una escolástica decadente sin restarle importancia a la del Siglo de Oro a la que también Menéndez Pelayo le rinde tributo. La Miscelánea Beltrán de Heredia es una colección de artículos sobre historia de la teología española, idea que se realizó en 1960 y que los dominicos recogieron en cuatro volúmenes dentro de la Biblioteca de Teólogos Españoles, Salamanca, 1971-72. En tiempos de la Restauración Don Marcelino tuvo problemas con este proyecto y se vió excluido de él.

35 Los articulos del P. Iriarte, Estudios sobre la filosofia, su concepto y su valor. Madrid, Razón y $\mathrm{Fe}$, Bolaños y Aguilar, 1947. 2 Vols. Pensares y Pensadores, Madrid, Razón y Fe, 1958. Nuevos Pensares, Madrid, Razón y Fe, 1958. En los años 1944-45 y 46 se publican en Razón y $\mathrm{Fe}$, varios articulos relacionados con la filosofia y los duelos con Menéndez Pelayo de varios sec. tores del pensamiento español.

36 Adolfo Muñoz Alonso. “¿Filósofo Menéndez Pelayo?". Revista de Filosofía, Tomo XV, 1956. Este articulo es una sintesis de su obra más completa Criterios de Menéndez Pelayo, Ed. Fax. Imp. F. Ramón Camacho, Granada, 1956.

37 Vease Adolto Bonilla y San Martín. Sus obras: Biografia de Menéndez Pelayo. Librería Victoriano Suárez, Madrid, 1911; Marcelino Menéndez y Pelayo 1856-1912. Edit. Real Academia de la Historia, Madrid, 1914; Ensayos de crítica filosófica, Madrid, 1919. López Arana. BBMP. Año 1919. pág. 40.

38 V. Palacio Atard, “Menéndez Pelayo. Historiador Actual». Arbor XXXIV, 1956, págs. 472. 445. Luciano Calzada, "La historia de España en Menéndez Pelayo". BBMP. XXXI1, 1956, pp. 219-292. Véase también Bernardino Llorca «Menéndez Pelayo y la historia de la Iglesia Española". Arbor XXXIV, № 125-128, 1956. pp. 452-463, otra obra de "vindicación", pero como historiador eclesiástico. 
su influencia "santificante» en la sociedad europea descristianizada. Se deduce por el artículo de Atard que el revisionismo se limita tan sólo a dejar de lado excesos, leyendas negras y doradas para encarar la historia como Menéndez Pelayo la quería, sin polémicas ni equívocos.

El Centenario no era clima favorable para avanzar en una historiografia más objetiva. Las contribuciones de José Maria Pemán en Arbor sobre el Tradicionalismo de Menéndez Pelayo «La Institución Católica de Don Marcelino" ${ }^{39}$, y Las Palinodias de Don Marcelino de Dámaso Alonso ${ }^{40}$ sobre su humanismo clasicista, tampoco aclaran el panorama. El libro de Dámaso Alonso al menos apuntaba hacia futuros estudios sobre las ideas estéticas y artísticas de Don Marcelino en un marco más histórico que el de Melchor Fernández Almagro, José Aznar y Hans Juretschte ${ }^{41}$. Habria que esperar hasta 1962, con los estudios de Pedro Sáinz Rodríguez sobre La Evolución de las ideas sobre la decadencia española y otros estudios de crítica literaria, en el cual se incluye un capitulo "Menéndez Pelayo historiador y crítico " ${ }^{42}$ para revalorizar históricamente el problema de Don Marcelino con la estética neocatólica de su tiempo.

A pesar de que todavía sobreviven en 1963 historias partidistas como la Historia de la Iglesia Católica de la B.A.C. ${ }^{43}$, en los años sesenta comienzan a aflorar estudios más objetivos del siglo XIX, de sus personalidades y de Menéndez Pelayo ante la Restauración. Desde Asturias José

39 J.M. Pemán, "La IJustración Católica de Don Marcelino". Arbor XXXIV, № 125-128, 1956. pp. 337-358. En este artículo a M. Pelayo se le denomina tradicionalista a la manera del siglo XVIII con el espiritu renovador de Forner, Capmany, Burriel, Bayer y Balmes.

40 Dámaso Alonso, Menéndez Pelayo crítico literario (Las Palinodias de Don Marcelino. Ed. Gredos, 1956. Del mismo año "Menéndez Pelayo, historiador de la literatura y crítico literario", Arbor, № 125-128; 1956. pp. 344-358

41 M. Fernández Almagro, «Menéndez Pelayo y los estudios clásicos", Arbor XXXIV, $N^{\circ} 125$. 128, 1956. págs. 384-409. J. Ramón Aznar, "Menéndez Pelayo y la Estética", Arbor XXXIV, $N^{\circ}$ 125-128; 1956, págs. 446-448. H. Juretschke, Menéndez Pelayo y el Romanticismo, Ed. Nacional, Madrid, 1956.

42 Pedro Sáinz Rodriguez, Evolución de las ideas sobre la decadencia española y otros estudios de crítica literaria. Rialp, Madrid, 1962.

43 En la Historia de la Iglesia Católica de la B.A.C., Madrid, 1963, la sección dedicada al siglo XIX "La Iglesia y el Estado en España y Portugal», tomo V, págs. 525-591, a cargo de R. García Villoslada, S.J., es predominantemente tendenciosa en su trato de la Restauración. El autor deja de lado su objetividad científica para descargarse contra los intelectuales del 98 , contra Giner de los Rios, a quien llama "el santón laico, cuya misión era laicizar a España», pág. 563. Unamuno, la Institución Libre de Enseñanza, la Junta para Ampliación de Estudios, son responsables, para el autor de esta historia, de que "a la más alta figura en el orden de la inteligencia y de la cultura, D. Marcelino Menéndez Pelayo (1912) le iban relegando a la sombra del olvido". pág. 563. A Menéndez Pelayo se le dedica un estudio "Menéndez-pelayista" para sacarle del olvido; véanse págs. $575-578$. 
María Cachero ${ }^{44}$, el Padre San Emeterio Cobo desde el Boletin de Santander, inician esta nueva etapa. "Dos años en la lucha en la vida política de Menéndez Pelayo" de San Emeterio Cobo recoge material de la prensa neocatólica de la Restauración para poner definitivamente en el tapete, las polémicas de Menéndez Pelayo con el catolicismo de la Restauración ${ }^{45}$.

En 1962 Fernando Lázaro Carreter publica una nueva biografía de Menéndez Pelayo tomando en cuenta el ambiente político de la Restauración ${ }^{46}$. Pero no se pierden del todo ciertos resabios de Menendezpelayismo intransigente que niegan la evolución ideológica de Menéndez Pelayo y contestan a Laín y Tovar su supuesto liberalismo decimonónico, del cual se culpa a Cánovas. Lázaro Carreter también recurre a la "superioridad" de Don Marcelino, volando con su mirada más allá que la de sus adversarios para evadir las cuestiones internas.

En 1966 José Manuel Cuenca Toribio en otra biografia de Menéndez Pelayo ${ }^{47}$ toma más en serio el contexto político religioso y discute a Don Marcelino como personalidad compleja y problemática. Cuenca consulta epistolarios y acepta la evolución ideológica de Heterodoxos o las Estéticas; con una actitud más crítica discute la ortodoxia de Don Marcelino, pero no llega al fondo de la Cuestión Religiosa como ortodoxia ultramuntana.

En 1973, un profesor francés, André Barón desde el Boletín, bajo la dirección de Ignacio Aguilera se lamenta de ver a Menéndez Pelayo reducido a símbolo de una nación fraticida, y pide que cesen las simplificaciones y falsificaciones de su pensamiento ${ }^{48}$. Las opiniones de Barón eran ya signo de que en los años setenta se podian expresar abiertamente desde el Boletín, ciertas realidades ocultas. En los años ochenta, bajo la dirección del Dr. Manuel Revuelta Sañudo, actual director de la Biblioteca de Menéndez Pelayo, se ha puesto en marcha una auténtica revalorización

\footnotetext{
44 José Maria Cachero Menéndez Pelayo y Asturias. Instituto de Estudios Asturianos, La Cruz, 1957.

45 . M. San Emeterio Cobo, “Dos Años de lucha en la vida politica de Menéndez Pelayo", BBMP, XXXVIII, 1962, pp. 5-150. Del mismo autor Menéndez Pelayo. Su época y su obra literaria. Madrid, 1962; y Antropologia cultural en Menéndez Pelayo, Universidad Complutense, Madrid, 1974.

46 Fernando Lázaro Carreter. Menéndez Pelayo. Vida y obra de Menéndez Pelayo, Edit. Anaya. Madrid, 1962.

47 José Manuel Cuenca Toribio. "Marcelino Menéndez y Pelayo", Ediciones Cid, Madrid, 1966.

48 Andrés Barón. "Más sobre el Krausismo", BBMP, 1972. pp. 3-141; «Menéndez Pelayo ante la Francia de su tiempo". BBMP, 1973. pp. 3-128; 177-354.
} 
del personaje histórico, comenzando por la reorganización y publicación de su extenso epistolario, fuente historiográfica imprescindible para esclarecer el polémico ambiente de la Restauración.

El último toque de Menendezpelayismo que merece mención es el de la conferencia ya citada de Don Pedro Sáinz Rodríguez Menéndez Pelayo. Ese Desconocido. La evolución de Don Pedro Sáinz desde su actuación en Acción Española, pasando por su colaboración en el proyecto del Instituto de España en el 39, hasta su última conferencia del 75, marcan el despegue y ocaso del Menendezpelayismo, y del mito militante de Menéndez Pelayo que desaparece con la muerte de Franco.

Sáinz Rodríguez comenzó como constructor del mito nacionalista y acabó públicamente reconociendo su devastadora y deformante influencia en Menéndez Pelayo. Con sinceridad afirma que "Menéndez Pelayo ha sido objeto de captación y añado que soy culpable en este terreno". Sin embargo en Sáinz Rodriguez hubo siempre, desde sus primeros trabajos en el Boletín de 1919 y en su "Menéndez Pelayo Historiador y Crítico", una cierta honestidad histórica que le acercaba a las realidades conflictivas en la vida de Don Marcelino. De los tres grandes menéndezpelayistas, junto a Artigas y Sánchez Reyes, sus trabajos fueron los más perceptivos respecto a la ortodoxia católica del polígrafo. En 1975 mantiene esa misma integridad histórica, pero esta vez admitiendo su participación en un proceso que acabó "mixtificando" y "falsificando" a Don Marcelino. En cuanto a la labor de construir una cultura nacional de su pensamiento, ésta fue un total fracaso. Ya en 1962 anticipaba Sáinz Rodríguez el colapso de esta literatura apologética y antológica: "Recoger, pues, textos con otro de sus últimos escritos puede conducir a construcciones erradas". $Y$ en este mismo ensayo comenta: "Es notorio lo mucho que en estos últimos años se ha escrito sobre Menéndez Pelayo, casi en su totalidad está destinado a extraer de sus escritor los elementos doctrinales para elaborar una teoría en la que se base una política de afirmación nacionalista. La trascendencia de su obra enfocada desde este punto de vista es evidente, aunque como todos los doctrinarismos políticos, se presta a las interpretaciones y a las polémicas sus obras, divulgando sus escritos, ha dado gran impulso a toda esta literatura apologética o de exégesis" ${ }^{49}$.

En 1975, Sáinz es más explicito en sus denuncias, alegando que esta figura «que se anunciaba como una gloria nacional, para adscribirla a un

44 P. Sảinz Rodríguez, “Menéndez Pelayo historiador y crítico”, en Evolución, pág. 431-433 
sector político" fue "víctima de captación; constantemente unos y otros procuran atraérsele, hacérsele suyo. $Y$ justamente estas maniobras hacen que surjan contra él los de la acera de enfrente y de ahi viene una especie de falsificación de la figura, de la psicología y de la personalidad del gran escritor" (pág.).

Para aclarar esta situación Sáinz comienza rechazando las etiquetas y encasillamientos, sin aceptar como válidos los títulos polémicos de "tolerante», "intolerante», "integro" o "católico liberal decimonónico». Reconoce tan sólo al escritor decimonónico que desde su juventud maduró y evolucionó, tomando posturas distintas que hay que analizar cuidadosamente y sin pasión. Tampoco acepta Sáinz Rodríguez fórmulas vagas como las "palinodias» de Dámaso Alonso, que no profundizan seriamente en el pensamiento decimonónico del polígrafo. A Don Marcelino, propone, hay que estudiarlo en el contexto europeo, y no exclusivamente en el español. Es dentro de la problemática del Concilio Vaticano I y del Syllabus de 1864 , como reacción contra la secularización y el positivismo científico, como mejor se entiende la problemática del intelectual católico. Sáinz Rodríguez enfoca correctamente el tema, orientando futuros estudios históricos sobre la Cuestión Religiosa de la Restauración y a Menéndez Pelayo dentro de ella.

Lo que es evidente en 1975 es el total fracaso del Menendezpelayismo en formar una juventud dentro de una conciencia nacional que no servia para la democracia. A los jóvenes, Menéndez Pelayo les llegaba como un "desconocido", o como un mito desafortunado. Cuarenta años de Menendezpelayismo se desmoronaban con el Nacional Catolicismo franquista que le había dado vida y vigor polémico. Sáinz Rodríguez era la voz de este fracaso, la primera retractación pública de un sistema que había perdurado pero que no había logrado formar juventudes. Ante el retorno de las democracias comienzan las "meas culpas" de sus protagonistas. Célebres forjadores del Menendezpelayismo en todos sus matices se inician en la transición abandonando el ideario de Menéndez Pelayo.

Lo que resta del mito es una ignorancia y descuido histórico de una personalidad que bien entendida representa un vivo testimonio de lo que significaba convivir con la ortodoxia de Vaticano I. Pero como tampoco se pueden borrar de su historia, más de medio siglo de "mitificaciones" e idearios católicos nacionalistas, conviene "deslindar los campos" claramente entre lo "mítico" y lo "histórico", para que nuevamente no se pongan en marcha otros inventos culturales de carácter nacionalista que arrastran inconscientemente a nuevas fórmulas "transcendentales" de la vida y obra de Menéndez Pelayo. 